\title{
Illustrations of Domestic Architecture, from Popular Medieval Writers
}

\section{T. Wright}

To cite this article: T. Wright (1844) Illustrations of Domestic Architecture, from Popular Medieval Writers, Archaeological Journal, 1:1, 212-221, DOI: 10.1080/00665983.1844.10850525

To link to this article: http://dx.doi.org/10.1080/00665983.1844.10850525

曲 Published online: 10 Jul 2014.

Submit your article to this journal $\pi$

Q View related articles $₫$ 
representation of an inscription is required. It is even practicable, by varnishing the paper with a spirituous solution of lac, to obtain from it a cast in plaster of Paris; such simple and ingenious processes are invaluable to those who know the importance of minute accuracy in their researches, and furnish authorities for reference, which no drawing or transcript, however carefully made, can ever supply.

ALBERT WAY.

\section{ILLUSTRATIONS OF DOMESTIC ARCHITECTURE,}

\section{FROM POPULAR MEDIEVAL WRITERS.}

Hitherto the purely literary monuments of the middle ages have been little used for the illustration of architectural antiquities, in spite of the interesting materials which they furnish, more especially for domestic architecture, of which we have so few existing remains of an earlier date than the fifteenth century. The literary monuments of the middle ages are varied and numerous, and we may form them into a series of short articles, arranging them according to dates, so as to preserve the historical order of the variations in style, and according to the class of literature to which they belong, which will keep distinct the architectural monuments of each order of society. At present, I propose to take the Fabliaux, or popular metrical tales, which belong in date exclusively (or nearly exclusively) to the thirteenth century, and which describe the domestic manners of the middle and lower orders of society. The subjects of the fabliaux (which are written in French and Anglo-Norman) are chiefly low intrigues, which, from their nature, give us an insight into the arrangement of the dwellings of the peasantry and bourgeoisie.

The common name for a house was a manor (Fr. manoir, Lat. manerium, from manere), without any apparent distinction of character or dimensions. In the Diz dou soucretain (Meon. 
tom. i. p. 318), the house of the burgher (bourgeois) is described by this title :-

Jà Dieu plasce ce soit voir

Que vous vandiez nostre manoir.

In the fabliau Du bouchier d'Abbeville (Barbazan, iv. 1), the house of the priest is called a manor-

Venuz est au manoir le prestre:

while in the fabliau Du vair palefroy (Barbazan, i. p. 164.) the same term is applied to the residence of a knight, which appears by the context to have been rather what we should now call a fortified manor-house than a baronial castle :-

- avoit la seue forterece

De grant terre et de grant richece;

Deus liues ot de l'un manoir

Jusqu' à l'autre.-

At the period of which we are speaking (the thirteenth century) the houses of the people had in general no more than a ground-floor, of which the principal apartment was the aire, aitre, or hall (atrium), into which the principal door opened, and which was the room for cooking, eating, receiving visitors, and the other ordinary usages of domestic life. Adjacent to this was the chamber (chambre), which was by day the private apartment and resort of the female portion of the household, and by night the bed-room. We might give many extracts shewing the juxtaposition of the chamber and the hall. In the fabliau D'Auberée (Jubinal, Nouveau Recueil, i. p. 199), the old woman, visiting the burgher's wife, is led out of the hall into the chamber to see her handsome bed:-

Maintenant se lieva la dame,

Et puis dame Auberee apres,

Qu'en une chambre ilueques pres

Enmedeus ensamble en entrerent.

And when the lady has taken refuge with Dame Auberee, who holds a much lower rank in society and is represented as very poor, she takes her in the same manner out of the hall into her chamber :-

Lors l'a menee por couchier

En une chambre, iluec de joste.

Strangers and visitors generally slept in the hall, beds being made for them apparently on the floor. In the fabliau $D u$ F f 
bouchier d'Abbeville (quoted above), the butcher sleeps in the hall, which is only separated from the chamber in which the priest and his mistress sleep by a door, and he lifts the latch to enter the chamber and take leave of his hostess in the morning :-

En la chambre, sanz plus atendre,

Vint a la dame congie prendre:

La clique sache, l'uis ouvri.

In the fabliau Du munier diArleux (printed separately by M. Michel), they make a bed for the young maiden who is detained all night, in the hall beside the fire:-

Qant orent mangie et beu,

$\mathrm{Li}$ lis fu fais delés le fu

U la meschine dut couchier.

Sometimes, however, the whole family appear to have made their beds indiscriminately with strangers in the hall, although both sexes slept naked, for there was little delicacy of manners at this period. The story of two French fabliaux analogous to Chaucer's Reves Tale, turns on this indiscriminate position of the beds in the hall. The house was in general very much exposed. In the fabliau $D u$ clerc qui fu repus deriere l'escrin (Meon. i. 165), a man enters the hall, and seeing no one there, boldly knocks at the chamber door. In the fabliau Du meunier d'Arleux, the outer door of the hall is left unlatched at night, although a young maiden is in bed by the fire-side. In the fabliau Du prestre crucifie (Meon. iii. 14), the maker of crucifixes returning home at night, before he opens the door sees his wife and her gallant in the hall through a hole in the wall:-

A son hostel en est venuz,

Par un pertuis les a veuz,

Assis estoient au mengier.

In the fabliau Des treces (Meon. i. 343), the gallant enters by night through the window into the chamber in which the man and his wife are sleeping. In the fabliau $D u$ segretain moine (Barbazan, i. p. 242), the monk takes liberties with the lady as they are seated by the fire in the hall, which she repulses because they are exposed to the view of those who pass on the road:-

Quar ge crieng que la gent nos voient

Qui trespassent parmi la voie:

En cele chambre m'en portez. 
The chamber is here distinctly pointed out, as being adjacent to the hall. We may quote as another proof of this the fabliau Des trois dames qui trowverent un anel (Barbazan, iii. 220), where the lady in her chamber sees what is passing in the hall par un pertuis.

A stable was also frequently adjacent to the hall, probably on the side opposite to the chamber or bed-room. In the fabliau of Le povre clerc (Meon. i. 104), the same story as Dunbar's tale of the Friar of Berwick, when the miller and the clerk, his guest, knock at the door of the miller's house, the wife urges the priest, who is with her in the hall, to hide himself in the stable (croiche) :-

\section{Esploitez vos tost et muciez \\ En cele croiche .... \\ Tantost en la croiche s'elance.}

From the stable the priest looks into the hall through a window, which must have been in the partition wall:-

Et il m'aquialt a esgarder

Tot autresin conme li prestres

Qui m'esgarde des fenestres

De cele creche qui est la.

Behind the house was the court or cortil, which was surrounded by a fence, and included the garden, with a bersil (or sheep-cot), and other out-houses. The back door of the hall opened into this court. In the Diz dou soucretain (Meon. i. 318), the gallant comes through the court, and is let into the hall by the back door. In the fabliau Du prestre et d'Alison (Barbazan, iv. 427), a woman is introduced into the chamber by a false or back door, whilst the hall is occupied by company :-

En une chambre, qui fu bele,

Mist Herceloz Aelison,

Par uns fax huis de la maison.

The arrangements of a common house in the country are illustrated by the fabliau De Barat et de Haimet (Barbazan, iv. 253). Two thieves undertake to rob a third of "a bacon" which he (Travers) had hung on the beam or rafter of the hall :-

Travers l'avoit à une hart

Au tref de sa meson pendu.

The thieves make a hole in the wall by which one enters, 
without waking Travers or his wife, although the door of their chamber was open. The thief who had entered

Rampa tant de banc en astel,

Qu'il est venuz au hardeillon

Oú il vit pendre le bacon.

The whole description leads us to suppose the house in this instance to have been built chiefly of wood. Travers, now disturbed, rises from his bed, goes from his chamber into the hall and thence direct into the stable. After he has recovered his bacon and while he is boiling it over a fire in the hall, the thieves come and quietly make a hole in the roof to see what is going on below:

Puis est montez sor le toitel,

Si le descuevre iluec endroit

La où la chaudiere boloit.

The houses of knights and gentlemen seem to have consisted frequently, at this period, of the same number and arrangement of apartments. In the fabliau $D u$ sot chevalier (Barbazan, iv. 255), a party of knights overtaken by a storm seek shelter at the residence of the knight who is the hero of the tale: they pass through the court or garden to reach the house :-

Atant sont en la cort entre,
Puis sont venu en la meson
Ou li feus ardoit de randon.

This was the hall, where they stopped and where dinner was served; after which beds are made there for them, and the host and his lady go to sleep in the chamber, which is separated from the hall only by a doorway :-

\section{Ainz qu' il aient le sueil passé.}

During the night, the knight comes from his chamber into the hall to seek a light; which leads to the denouement. Even in the castellated buildings the bed-chambers appear to have been frequently adjacent to the hall; in the fabliau of Guillaume au faucon (Barbazan, iv. 407), William enters first the hall, and goes out of it into a bed-chamber, where-

-la dame seule trouva;

Les puceles totes ensamble

Erent alees, ce me sanble,

En une chambre d'autre part-

that is, as appears by the sequel, on the other side of the hall. 
The passages hitherto adduced relate to the more humble of the two classes of dwellings of the middle and lower ranks of society. The second class, which belonged to richer persons, differed from the former only in having an upper floor, commonly termed a soler (solarium, probably from sol). In the fabliau D'Estourmi (Barbazan, iv. 452), a burgher and his wife deceive three monks of a neighbouring abbey who make love to the lady: she conceals her husband in the soler above, to which he ascends by a flight of steps :-

Tesiez, vous monterez lá sus

En cel solier tout coiement.

The monk, before he enters the house, passes through the court (cortil), in which there is a sheep-cot (bercil). The husband from the soler above looks through a lattice or grate and sees all that passes in the hall :-

Par la treillie le porlingne.

The stairs appear, therefore, to have been outside the hall, and there seems to have been a latticed window looking from the top of the stairs into it. The monk appears to have entered the hall by the back-door, and the chamber is in the story shewn to be adjacent to the hall (as in houses which had no soler), on the side opposite to that on which were the stairs. When another monk comes, the husband hides himself under the stairs (souz le degre). The bodies of the monks (who are killed by the husband) are carried out parmi une fausse posterne which leads into the fields (aus chans).

In the fabliau of La Saineresse (Barbazan, iii. 452), a woman who performs the office of bleeding comes to the house of a burgher, and finds the man and his wife seated on a bench in the hall :-

En mi l'aire de sa meson.

The lady says she wants bleeding, and takes her up stairs into the soler :-

Montez la sus en cel solier,

Il m'estuet de vostre mestier.

They enter and close the door. The apartment on the soler, although there was a bed in it, is not called a chamber, but a room or saloon (perrin) :-

Si se descendent del perrin,

Contreval les degrez enfin

Vindrent errant en la maison. 
The expression that they came down the stairs and into the house shews that here also the staircase was outside.

In another fabliau De la borgoise d'Orliens (Barbazan, iii. 161), the burgher comes to his wife in the disguise of her gallant, and the lady discovering the fraud locks him up in the soler, pretending he is to wait there till the household is in bed:-

Je vous metrai priveement

En un solier dont jai la clef.

She then goes to meet her ami, and they come from the garden (vergier) direct into the chambre, without entering the hall. She tells him to wait there while she goes in there (la dedans) to give her people their supper :-

Amis, fet-ele, or remaindrez

Un petit, et çi m'atendrez;

Quar je m'en irai la dedens,

Por fere mangier cele gens.

She then goes into the hall :-

Vint en la sale à sa mesnie.

She afterwards sends her servants to beat her husband, pretending him to be an importunate suitor whom she wishes to punish : "he waits for me up there in that room:"-

La sus m'atent en ce perin.

Ne souffrez pas que il en isse,

Ainz l'acueillier al solier haut.

They beat him as he descends the stairs, and pursue him into the garden, all which passes without entering the lower apartments of the house.

The soler or upper part of the house appears to have been considered the place of greatest security-in fact it could only be entered by one door, which was approached by a flight of steps, and was therefore more easily defended. In the beautiful story De l'ermite qui śacompaigna à l'ange (Meon. ii. 216), the hermit and his companion seek a night's lodging at the house of a rich but miserly usurer, who refuses them admittance into the house, and will only permit them to sleep under the stair-case, in what the story terms an auvent or shed. The next morning the youth (vallet) goes up stairs into the soler to find the usurer, who appears to have slept there for security :-

Le vallet les degrez monta,

El solier son hoste trova. 
The soler appears also to have been considered as the place of honour for rich lodgers who paid well. In the fabliau Des trois avugles de Compiengne (Barbazan, iii. 398), three blind men come to the house of a burgher, and require to be treated better than usual. He shews them up stairs :-

En la haute logis les maine.

A clerk, who follows, after putting his horse in the stable, sits at table with his host in the hall, while the three guests are served "like knights" in the soler above :-

Et li avugle du solier

Furent servi com chevalier.

It may be observed that a stable was a necessary part of a common house, because at this period all householders were in the habit of letting or giving lodging to travellers, who generally came on horseback.

By the kindness of the Rev. Lambert B. Larking, vicar of Ryarsh in Kent, I am enabled to illustrate the foregoing extracts by a sketch of the manor-house of a country gentleman of the thirteenth century. It is represented on a seal in a perfect state of preservation attached to a deed by which William Moraunt grants to Peter Picard an acre of land in the parish of Otteford in Kent. It is dated in the month of June, 56 Hen. III. (i. e. June, 1272). The inscription is s. Willelmi moravnt. The door, which is probably that which led to the hall, is represented apparently as opened outwards. It is altogether a

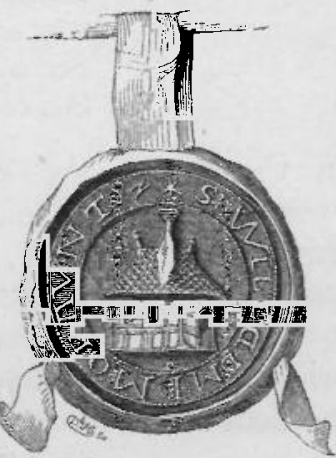
curious illustration of early domestic architecture.

In the fabliau Du vair palefroy (Barbazan, i. 164), we have a picture of the castellated manor-house of a wealthy knight. A young knight who had spent his substance, who lived at no great distance, was in love with the rich knight's daughter, but was not allowed to have access to her. The " manor" in which the lady was confined was built on a rock adjacent to a forest. The court, or garden, was large and was surrounded by a foss, lined inwardly with a fortified defence which appears to have been a thick hedge of thorn (espinois), strengthened in ex- 
posed parts with planks. The entrance was by a gateway and drawbridge :-

Mess molt estoit granz li defoiz,

Quar n'i pooit parler de pres:

Si en estoit forment engrès

Que la cort estoit molt fort close.

La pucele n'ert pas si ose

Qu'ele de la porte issist fors;

Mes de tant ert bons ses confors

Qu'a lui parloit par mainte foiz

Par une planche d'un defoiz.

Li fossez ert granz par defors,

Li espinois espes et fors,

Ne se pooient aprochier:

La meson ert sor un rochier,

Qui richement estoit fermee;

Pont leveis ot a l'entree.

The young knight goes to the "manor" of his uncle, and for the sake of privacy they enter a "lodge" over the gateway :

En une loge sor la porte

S'en sont ale priveement,

Son oncle conta bonement

Son convenant et son afere.

In the sequel the vair palefrois carries the lady to the "manor" where the young knight lived. This manor was surrounded by water, and a bridge led to the gateway. The watchman, who was "above the gate," was sounding his horn to announce day-break, when he heard the horse on the bridge; he then descended and challenged the rider from the door :-

- la guete ert desus la porte,

Devant le jor corne et fretele.

Cele part vait la damoisele;

Droit au recet en est venue.

Ainz li palefroiz de sa voie

N'issi, si vint desus le pont

Qui sist sor un estanc parfont :

Tout le manoir avironoit;

Et la guete qui la cornoit

Oi desus le pont l'effroi

Et la noise du palefroi 
Qui maintes foiz i ot este.

La guete a un pou areste

De corner et de noise fere :

Il descendi de son repere,

Si demanda isnelement

Qui chevauche si durement

$A$ iceste eure sor cest pont.

Not satisfied with the answer of the lady, the watchman looks through a hole in the poterne (or smaller door for the admission of foot passengers), and recognises the palfrey :-

Il met ses iex et son viaire

A uns partuis de la poterne.

He then goes to the chamber of his lord to tell him what he had seen. The young knight hastily covered himself in a surcot, and came to the gate, which was opened to the stranger, who at first did not recognise her lover, but asked courteously for a night's lodging :-

\section{Sire, por Dieu ne vous anuit, \\ Lessiez moi en vostre manoir, \\ Je n'i quier gueres remanoir.}

In the morning the knight takes the lady "into his court and his chapel," by which it would seem that the chapel was entered from the court, and was perhaps on the opposite side to the house, and he calls his chaplain, who marries them :-
A lendemain quant il ajorne,
Dedenz sa cort et sa chapele
Venir i fet la damoisele.

I now quit this class of literary compositions; the long metrical romances of the same period describe the interior economy of the larger baronial castles, and will probably furnish materials for a future article.

T. WRIGHT. 